\title{
Urban Violence and Demographic Delimitations in Democratic Governance
}

\author{
Aluko Opeyemi Idowu* \\ University of Ilorin \\ Kwara State Nigeria
}

Received 15.10.2015, received in revised form 26.11.2015, accepted 03.12.2015

Urban violence has reached a global chaotic stage that requires urgent combat. Concise effort in recommending several way-out of this global menace had been made. Democratic delimitations have been identified in this work as a source of reoccurring urban violence in most polities. These include state creation, zoning formula, affirmative action and federal character principles. With regards to these efforts, the question this work asked is that what are the effects of demographic delimitations on democratic peace which may appear invisible but potent and volatile in the polity? Relative deprivation theory is used to validate the facts that urban violence is as a result of depriving group of people of their rights and benefits. The research methodology adopted is the analyses of the afrobarometer database on national and ethnic identity, security handling and general economic level perception. Two thousand four hundred respondents each in Nigeria, Ghana and South Africa respectively are focused in this study. The recommendations posited centres on ensuring adequate representation among the federating units in a country in terms of fiscal and critical geographical differences. The conclusion however centres on the facts that violence ensuing from geographical delimitations are easily escalating but when the geographical differences are streamlined peace will ensue.

Keywords: Zoning formulas, Affirmative action, State Creation, Federal Character, Urban Violence and Relative Deprivation.

DOI: 10.17516/1997-1370-2016-9-1-251-264.

Research area: politology.

\section{Introduction}

Urban violence from a universal peace orientation has reached a global chaotic stage where both man and his environments are in jeopardy of their lives and existence at every instance of an occurrence of such violence. This no doubt shows that urban violence requires an urgent attention of combats. Concise effort however had been made severally by both the town and the gown by the way of recommending several way-out of this global menace.

With regards to these painstaking efforts of proffering political, socio-cultural and economic solutions and recommendations, the menace of urban violence still persists in most polities of the world. This means that there are some salient spots and lurking variables which supports and makes violence to survive all precautions, medications and treatment in every polity of the

(C) Siberian Federal University. All rights reserved

* Corresponding author E-mail address: opealukoheavenprogress@gmail.com 
world (Parlette and Cowen 2010). The question this work seeks answers to is that what are the salient points or issues of continuous violence which may appear invisible but potent and volatile in the polity?

Democratic delimitations have been identified in this work as a silent but salient source of reoccurring urban violence in any polity. People's fundamental rights are of topmost priority to them at any point in time. Whatsoever that tries to either ulcerate or out rightly cancel it is seen as object of retrogression in the lives and the entire environment of the people. These violent sources might be eliminated with either peaceful legislative means peaceful dialogue. The demographic delimitations considered in these work include; state creation, zoning formula, affirmative action and federal character principles.

Relative deprivation theory is used in this work to validate the facts that urban violence is as a result of depriving the people of their rights and benefits. This eventually cumulates into factors that have resultant effect on violence in the community. The research methodology adopted is the analysis of the afrobarometer database on national and ethnic identity, security handling and general economic level of perception by two thousand four hundred respondents in democracies. Nigeria Ghana and South Africa are focused in this study but a general inference on the realities in Africa and many developing countries of the world.

The recommendations posited in this work centres on ensuring adequate representation among the federating units in a country in terms of fiscal and critical geographical differences. The recognition of major strength and weakness of each federating groups so as to adequately supply their needs is also necessary for policy formulators to take note. The conclusion however centres on the facts that violence ensuing from geographical delimitations easily escalate from one aggrieved group to the other in the polity but when the geographical differences are streamlined peace will ensue and abound.

\section{Conceptual clarification}

Several concept needs clarification in this work but a few will be clarified so as to ensure clarity of the true picture of the terms and the line of arguments which cumulate to violence in it execution as explain in this work. Such concept include; Demographic Delimitation and its elements such as Federal Character, Zoning formulas, Affirmative action and State Creation. Another major concept to be clarified is Urban Violence.

Delimitation and demarcation are terms used to describe aspects of the process of boundary definition. Traditionally, delimitation has been used to refer to the definition of a boundary in a treaty or other legal instrument, while demarcation refers to the physical marking of the boundary on the ground (Donaldson 2014). Lamamra (2014) however reacted that the delimitation and demarcation initiative meets three imperative needs:

The first is geopolitical, concerning the peace, security and stability that derive from conflict prevention. The Programme does not aim for a new 'Balkanization'; rather, it is a way to reinforce State territorial sovereignty that brings with it the freedom to open up and integrate. The second need is geo-economics: a visible, well-managed border encourages trade. The third need is socio-economic, as local cross-border cooperation initiatives between committed neighbouringcommunitiescanbesupported. Africa's borders should therefore become a source of peace, security, and integration for the continent. They should constitute a 
perfect equation, harmoniously balancing all relevant factors - including the legal determinants and human realities on the ground - to promote the shared, common values of the populations concerned.

Federal Character is a supporting principle that holds several division and groups in a polity together into a single entity. In the words of Majekodunmi (2013) the principle is essentially referred to as the recognition of the plural nature of the country in recruitment, distribution of administrative and political offices and power as well as the resources of the country. This means that geographical differences are streamlined by the application of this principle.

Also Ezeibe (2013) posited that the principle in federal character involves a deliberate plan to construct means of ensuring the proper distribution of amenities and government projects in a country. Taking it further, Okolo (2014) believed that federal character is introduced where there are observed differences in culture, tradition and inequality either in human, natural or both. Therefore, it is an analgesic principle aimed at uniting once existed autonomous subnationalities through quota system for purposes of equality of opportunities and peaceful coexistence.

Zoning formulas is not a popular concept to decipher because a few scholarly works is available on it. However, this can be said to be the process of elite selection by masterminds to rotate the right of occupancy of an office which is meant for the whole population in any given political system. This means that the giving out on rotational bases of an office among various groups of people situated in different places and separated by geographical location, language or religious believes but are joined together in a common political entity. Nwozor (2014) conceived it to be a political arrangement within a political party whereby political power is rotated among the party members so as to circulate the privilege of occupying a general political office to all the confederating members.

From the above view, zoning formula can be extrapolated to be a deliberate arrangement among the federating political groups in a state by creating an imaginary political geographical partition in the state so as to be able to rotate the right or privilege of occupying a major political office in the state to all the federating groups or entities so as to prevent struggling, scrambling and partitioning for political power at all cost and unnecessary domination of a group over the others which may eventually heat up the polity.

Affirmative action in the same vain as the zoning formula is also more of balancing the various divisions of the polity up. This might be gender base, ethnic base or individual economy level base. This is a kind of socio political arrangement and geographically base. Holzer and Neumark (2005) opined that Affirmative Action refers to a set of practices undertaken by employers, university admissions offices, and government agencies to go beyond nondiscrimination, with the goal of actively improving the economic status of minorities and women with regard to employment, education, and business ownership and growth.

University of Oregon (2003) opined that affirmative action is a process required of federal contractors to ensure equal employment opportunity. It requires a good-faith effort to achieve and maintain a work force in which women and people of colour are represented at a level commensurate with their availability in the labour pool from which the employer can reasonably be expected to recruit. Affirmative action also applies to individuals with disabilities and covered veterans with a focus on ensuring 
equal opportunity in connection with all aspects of employment.

State Creation also as a demographic delimitating method, is a geographical arrangement among the dwellers of a region to lawfully separate from one another as a means of expanding their territory or fragmenting their compact territory. It is also refer to as the breakup of a group of people in a formal territory or state to form a new territory usually within the formal established territories.

Moreover, state creation is also a political and social arrangement that takes one of the following forms; a form of boundary adjustment exercise to get a new state out of an established old state, a form of independence from colonial rule so that the natives gets the full rights to rule themselves, a form of rancour among federating units in a state which leads to forceful separation between the groups to have a new state.

Urban violence on the general view is more of making the state ungovernable and laws and orders are broken down. Krause, Muggah and Gilgen (2011) distinguish direct forms of urban violence which result in physical and psychological harm including intentional fatalities, assault and sexual violence and indirect manifestations that negatively affect other aspects of livelihoods, social relations and wellbeing. This concept agrees with the same trend of violence in general which may manifest in either the urban area or the rural area.

Muggah (2012) however concluded the whole gamut of urban violence by submitting that;

There is no agreed definition of what constitutes urban violence or how it should be measured.

However, there are parameters to the discussion that hinge on its direct and indirect characteristics, its intensity and duration, its spatial--socio characteristics,

\begin{abstract}
its intentionality and context. It is generally agreed that urban violence often features interconnected forms of insecurity and that it challenges narrow categories and classifications.

Multi-dimensional frameworks are emerging that attempt to explain different thresholds of urban violence.
\end{abstract}

\section{Theoretical framework}

\section{Deprivation Theory}

Gurr (1971) refers to Relative Deprivation (RD) as 'the tension that develops from a discrepancy between the 'ought' and the 'is' of collective value satisfaction, and this disposes men to violence'. According to the definition provided by Gurr, Relative Deprivation is the discrepancies between what people want, their value expectations, and what they actually gain, their value accruing capabilities.

Gurr further states that: 'the intensity of relative deprivation varies strongly in terms of the average degree of perceived discrepancy between value expectation and value capabilities'. He contends that people are more likely to revolt when they lose hope of attaining their societal values, and the intensity of discontent/frustration '[varies] with the severity of depression and inflation'. Ethnicity, Gurr asserts, 'is the obvious basis for mobilizing oppositions' against the state. Gurr states that, the higher the degree of frustration, the greater the political instability.

Esman (1994) argues that:

The concept of relative deprivation refers to the gap between a group's current status and prospects and what appear to be reasonable and legitimate expectations, or to a gap between what comparable groups are believed to enjoy and what is available in 
material, cultural, and political satisfactions to the collectivity and its members.

Relative deprivation theory distinguishes between egoistic deprivation and fraternal deprivation. Egoistic deprivation refers to a single individual's feeling of comparative deprivation. Fraternal deprivation, also called group deprivation, refers to the discontent arising from the status of the entire group as compared to a referent group.

\section{Demographic delimitation violence on democracy}

Demographic delimitation from it natural overlook is a good geopolitical and socioeconomic arrangement in an organised territory. The major perspective to the support of any form of demographic delimitation is for the greatest happiness of the greatest number of the people. However, demographic delimitations had been seen as a potential violence in every polity especially a democratic settings. The forms of demographic delimitations which is considered in this work that has added a magnitude of violence to democracies include; boundary adjustment, state creation, federal character principle, Zoning formula and affirmative action.

\section{Boundary Adjustment}

Several states had embarked on boundary adjustments in history. This cut across the states that emerged out of colonial rule in Africa, Latin America and Asia. Other states that had embarked on this action are in Europe and in Middle East. There are various laudable reasons for many states in embarking on this action. A major reason includes the proper capturing of neglected ethnic group members (Mayer 2003). This is seen in the some cases in Nigeria, Canada, United State of America and Israel. Other reasons are the recognition of some potential threat in some uneven distribution of land and resources within a state which might make a state more powerful and than the other within the state, the measures to curb inequality in land mass distribution within a state and the recognition of political consanguinity among group of people with their kit and kens in the another state.

This exercise is similar to that of the state creation but the observable difference is the that there is no entirely new state created or caved out of the existing ones but a mere adjusting of the land mass. There is no increase in the total number of states in the country or the entire world. It is usually an internal affair of the country in most cases and a few cases are between two states in the region. An example is the Nigeria-Cameroon boundary adjustment over the oil rich Bakassi Peninsula and that of Israel- Palestine Boundary tousle. The major adverse effect of boundary adjustment is the continuous need to change the dimension and readjusting of the agreement reached over time.

\section{State Creation}

The nexus between state creation and boundary adjustment is so strong that geographical boundary adjustment might lead to a form of new state creation. Several states of the world had one time or the other embarked on state creation. The major reasons claimed for such exercise is to cater for all the existing and conflicting entities that make up the state (Neha 2013). A major reason for new states creation agitations by most federating unit is gross marginalization by the majority and dominating group. Deeply divided multi ethnic groups in a state do often leads to segregation, rancour and acrimony therefore the ready remedy is to selectively separate the groups into different states within the same polity.

Another cogent reason why state creation is eminent is religious separatist elements 
(Eugene 2007). There will always be religious violence between groups that have extreme religious believes. Therefore the resultant solution to the frequent conflict is either state creation within the general entity or a complete Balkanizing of the old state to create two or more new states.

\section{Federal Character}

Federal character principle like other federal structures is meant to cater for the inequality that might emerge from conflicting and domineering tendencies of some groups in the federating structure. This principle sees to the fact that various ethno religious groups in the state have the tendencies of causing a vital breakdown in the polity during agitation for adequate representation so a complete representation is provided which might be on the part of geographical or regional sect selection or on the socio economic bases.

There must be the distinctive desire of the people to promote thenational unity, fosternational loyalty and give every citizen a sense of belonging to the national structure notwithstanding the diversities of ethnic origin, culture, language or religion which may exist. The federal character principle essentially refers to the recognition of the plural nature of the country in recruitment, distribution of administrative and political offices and power as well as the resources of the country. The essence federal character principle is to allow the composition and conduct of public institutions and affairs that reflects the country's diversity.

The major claims against the principle of federal character include; the federal character principle has led the political elites to place too much emphasis on inter-state relationships without a corresponding attention to tensions among ethnic groups within the states. The federal character principle strives to give equal treatment to asymmetrical groups in the society. Many people perceive this principle or policy as being discriminatory. The interpretation of federal character, which is based on state and ethnicity, is seen by many as inadequate and bias (Fourchard 2010).

In Nigeria, Ghana and South Africa for instance, the social divisions are not limited to ethnic and state; there are also class, professional, confessional, temporal and ideological divisions. The operation of the federal character principle in most democracies tends to give more powers to the politically dominant groups; creating wider power disparity between the stronger and weaker groups, and thereby, subjecting the politically weaker groups to double jeopardy of losing power and structural subjection to institutional subjugation.

\section{Zoning formulas}

Zoning formula is another democratic practice in most heterogeneous societies. This entails a geographical distribution of public offices to different zones or locations of the state. The geographical location might be carved out by religion bases, ethnic or political party rotational bases. This principle fits into most heterogeneous democracies. Simbine (2002) opined that the zoning formula seems to fit into the heterogeneous and federal nature of the Nigerian state and other multiethnic and religion societies. It helps to accommodate all groups as much as possible and therefore reducing complaints of domination and or marginalization. To this extent, it helps to make the system more inclusive (of identifiable groups), and therefore more supportive of the democratic culture.

Usually, there are certain conditions under which power sharing arrangement work out in achieving success towards resolving ethnic conflict within diverse polity. The following are among the conditions as seen by Sisk (1996) are: 
They should be embraced by a core group of moderate political leaders in ethnic conflicts and these leaders are genuinely representative of the groups they purport to lead. The practices should be flexible and allow for equitable distribution of resources. They should be indigenously arrived at, not agreed on as the result of too-heavy external pressures or short-term, zero-sum expectations of the parties. Parties can gradually eschew the extraordinary measures that some power sharing practices entail and allow a more integrative and liberal form of democracy to evolve.

\section{Affirmative action}

Affirmative Action refers to a set of practices undertaken by employers, university admissions offices, and government agencies to go beyond non discrimination, with the goal of actively improving the economic status of minorities and women with regard to employment, education, and business ownership and growth. This additional activity can take the form of special recruitment efforts to draw more applicants in these areas from the minorities and women groups, but might also include some additional consideration of or preference for these applicants, given that their credentials along certain dimensions might look weaker than those of their counterparts.

The roots of affirmative action in employment lie in a set of Executive Orders issued by United State of America Presidents since the 1960's. Executive Order 10925 (issued in 1961) introduced the phrase "Affirmative Action," encouraging employers to take action to ensure non discrimination. Most democracies of the world have also adopted this action so as to show fairness and equity to all the federating units of the state.
This action tends to curtail all forms of discriminations which have the power to cause political bigotry, economic dwarfism and geographical schism. Other corrections that affirmative action corrects are; offsetting of past discriminations which include racial discrimination, sexual discrimination ethnic group discrimination, religious discrimination and geographical discrimination. Other corrections include; to counteract present unfairness; and to achieve future equality among any group or individual in the state.

The major effects of all of the demographic delimitations above discussed on democracy are majorly felt on the extent of disparity it causes on the polity or the magnitude of unity accrued to the polity. The extent of disparity it causes on the polity is visible when the mechanism of their operations fails to materialise the desirable outcome. The following urban violence symptoms will therefore be visible in the polity; ethnic chauvinism, religious bigotry, national multi polarity, economic development mono concentration, political anarchism, psychological depression, frequent communal clashes which can be traced to ethnicity or religious alignments and at the final analysis, a polity collapse or failed state results.

On the other hand when all or most of these demographic delimitations adopted by a federal state or any democracy becomes functional and successful, there will be a great and high magnitude of unity accrued to the polity. Most of the urban violence indicators will be present but in a total reduced percentage or a total eradication of the urban violence symptoms might result. The following polity growth factors will therefore be visible in the polity; reduced ethnic consciousness, reduced religion disparity, reduced national multi polarity (division) to mono polarity or neo polarity. Also the economic development will be evenly concentrated and distributed, 
political statesmanship consciousness develops in the minds of the greatest number of the people, the psychological state of mind of the people becomes exited towards state building, reduced to the minimal level of the communal clashes and at the final analysis, a viable state is formed and consolidated with the greatest happiness of the greatest number of the people.

\section{Methodology}

The methodology adopted uncovers the perception of people in Nigeria, Ghana and South Africa on the democratic implications of demographic delimitations adopted in their various multiethnic federal structures. The research conducted by afrobarometer round five (5) in 2012-2013 is used; validated and interpreted. The total sample size is two-thousand four hundred (2400) participants across each country. The sample selection technique is simple proportionate purposive random sampling. Simple percentage, ratio and graphical illustrations will be use as the analytical tool to analyse the result.

This research is appropriate as it reflect the true mind set of Nigeria, Ghana and South Africa populace on the unending dimensions of urban violence in the country. It answers the question of what are the effects of demographic delimitations on democratic peace which may appear invisible but potent and volatile in the polity. It also reveals the perceptions of the people on their Country's present economic condition, handling and resolving violent conflict between communities, the ethnic or national identity allegiance among the populace and the extent of nationality pride they possesses.

\section{Discussion of finding}

\section{Country's Present Economic Condition}

From the Fig. 1 above, it is evident that the total perception of the people of Nigeria, Ghana and South Africa to seeing the country's economy as bad is quite high. Sixty seven percent (67\%) of perception of Nigerians sees the economy of the country as bad. Sixty four percent (64\%) of perception of Ghanaians sees the economy of the country as bad while forty seven percent (47\%) of perceptions of South Africans sees the economy of the country as bad. This shows that there are some lacunas in the polity which makes the efforts of the states on the economic matters to be poor and unyielding profitably to the majority. This might be invisible to the general populace such as the demographical delimitations. If not totally controlled it may further lead to an increase in the rate of urban violence in the polity.

Table 1

\begin{tabular}{|l|c|c|c|}
\multicolumn{1}{|c|}{ Total } & \multirow{2}{*}{ Nigeria } & Ghana & South Africa \\
\cline { 1 - 2 } Very bad & $39 \%$ & $40 \%$ & $19 \%$ \\
\hline Fairly bad & $28 \%$ & $24 \%$ & $28 \%$ \\
\hline Neither good nor bad & $8 \%$ & $6 \%$ & $17 \%$ \\
\hline Fairly good & $21 \%$ & $24 \%$ & $28 \%$ \\
\hline Very good & $4 \%$ & $6 \%$ & $6 \%$ \\
\hline Missing; Unknown & - & - & $2 \%$ \\
\hline Don't know & $1 \%$ & $1 \%$ & 2,399 \\
\hline Total & 2,400 & 2,400 & - \\
\hline
\end{tabular}




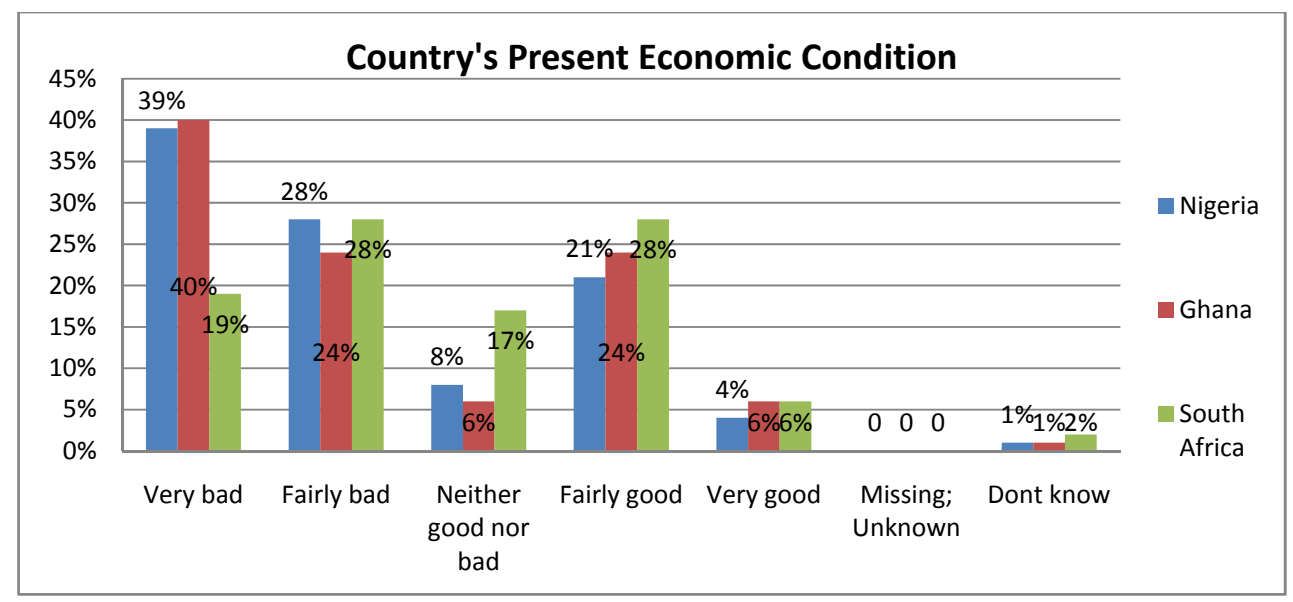

Fig. 1

Table 2

\begin{tabular}{|l|c|c|c|}
\hline \multicolumn{1}{|c|}{ Notal } & \multirow{2}{*}{ Nigeria } & Ghana & South Africa \\
\hline Very badly & & $15 \%$ & $18 \%$ \\
\hline Fairly badly & $30 \%$ & $19 \%$ & $31 \%$ \\
\hline Fairly well & $29 \%$ & $43 \%$ & $36 \%$ \\
\hline Very well & $33 \%$ & $20 \%$ & $10 \%$ \\
\hline Missing; Unknown & $7 \%$ & - & - \\
\hline Don't know; haven't heard enough & $1 \%$ & $3 \%$ & $5 \%$ \\
\hline Total & 2,400 & 2,400 & 2,399 \\
\hline
\end{tabular}

\section{Handling and Resolving}

\section{Violent Conflict between Communities}

From the Table 2 above, it is obvious that the way and manner the government of Nigeria handles violence in the state is not very effective. Forty percent $(40 \%)$ of the populace perceived it as well while a larger percentage perceived it as bad. This indicates that the invisible hands of demographical delimitations still have a firm grip on the polity in Nigeria. The case takes a slight turn around in the perception of the populace in Ghana. Sixty three (63\%) of the populace perceived the government's way of handling violence in the polity as well and good while a slightly significant percentage perceived it as bad.

This indicates that the invisible hands of demographical delimitations discussed in this work still have a grip on the polity in Ghana but not as firm as that of Nigeria. The case of South Africa is similar to that of Nigeria; Forty Six percent $(46 \%)$ of the populace perceived the government's way of handling violence in the polity as good and well in a modest way while a significant percentage perceived it as bad. This indicates that the invisible hands of demographical delimitations discussed in this work still have a firm grip on the polity in South 


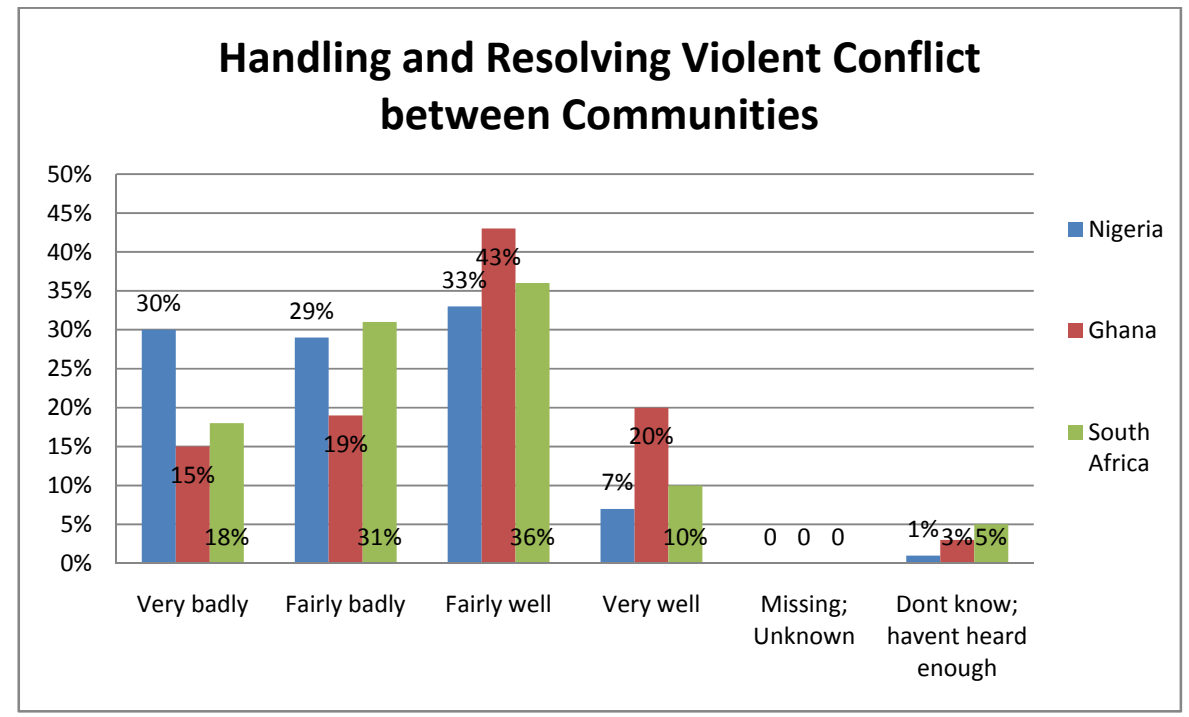

Fig. 2

Africa just very close to that of Nigeria but deviant to of Ghana.

\section{The Extent of Ethnic}

\section{or National Allegiance}

From the Table 3 above, it is evident that the ethnic alliance of all the democratic countries under observation seems to be low to what the national alliance is. This means that the extent of ethnic consciousness in relation to national stability consolidation is relatively low. But the case of Nigeria shows a slight boost in ethnicity as twenty one (21\%) feel more ethnically allied. However, this perception is crossed checked by the next perception of equality in alliance between the ethnic groups and the country's unity.

Sixty percent $(60 \%)$ and fifty one $(51 \%)$ of perceptions in Nigeria and Ghana respectively says they have equal alliance for both the ethnic groups and the country's integrity. This is a potential threat for the sovereignty of the countries involve if the democratic delimitating factors are false-fully dealt with. The case of South Africa is of little difference as twenty two (22\%) of the respondents claimed to fall to the category of ethnocentrism while about sixty two percent $(62 \%)$ of the total population claimed to be solely nationally allied.

\section{The Extent of National Identity}

The Fig. 4 above clearly indicates the extent to which the people can identify with national issues without ethnic bias. The result of all the countries under review shows that a strong identity is given to national issues. Nigerians perceptions showed that about seventy five percent (75\%) of the populace gives a national face to national issues. A majority of about ninety three percent ( $93 \%$ ) of the perception of Ghanaians will show a national face to issue that concern national or global attentions while about eight nine percent (89\%) of the perceptions of the South Africans will show a national face to issue that concern national or global attentions. This perception is judged as observed because the reality of the day is that the more the ethnic group or religious alliance groups participate in national issues, the more relevance they gain in the whole polity. Also, the political, social and economic largesse that will be accrued to the concerned groups will 
Table 3

\begin{tabular}{|l|c|c|c|}
\hline \multicolumn{1}{|c|}{ Total } & \multirow{2}{*}{ Nigeria } & Ghana & South Africa \\
\cline { 1 - 3 } I feel only for ethnic group & $4 \%$ & $0 \%$ & $2 \%$ \\
\hline I feel more for ethnic group than Country & $22 \%$ & $3 \%$ & $6 \%$ \\
\hline I feel equally for ethnic group and Country & $60 \%$ & $51 \%$ & $22 \%$ \\
\hline $\begin{array}{l}\text { I feel more for ethnic group than for } \\
\text { Country sometimes }\end{array}$ & $9 \%$ & $11 \%$ & $8 \%$ \\
\hline I feel only for Country & $5 \%$ & $34 \%$ & $0 \%$ \\
\hline Missing; Unknown & - & - & $0 \%$ \\
\hline Don't know & $1 \%$ & $0 \%$ & 0 \\
\hline
\end{tabular}

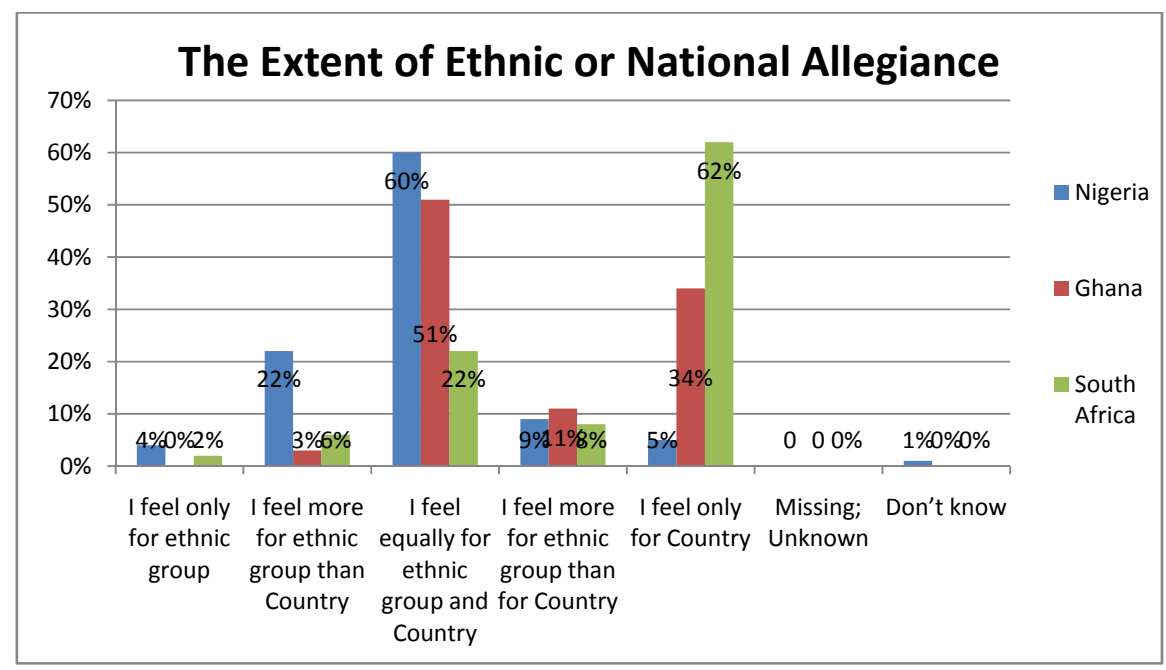

Fig. 3

Table 4

\begin{tabular}{|l|c|c|c|}
\hline \multicolumn{1}{|c|}{ Total } & Nigeria & Ghana & South Africa \\
\cline { 1 - 2 } Strongly disagree & $5 \%$ & $4 \%$ & $6 \%$ \\
\hline Disagree & $9 \%$ & $1 \%$ & $2 \%$ \\
\hline Neither agree nor disagree & $9 \%$ & $2 \%$ & $2 \%$ \\
\hline Agree & $37 \%$ & $24 \%$ & $29 \%$ \\
\hline Strongly agree & $38 \%$ & $69 \%$ & $60 \%$ \\
\hline Missing; Unknown & - & - & - \\
\hline Don't know & $1 \%$ & $0 \%$ & $0 \%$ \\
\hline Total & 2,400 & 2,400 & 2,399 \\
\hline
\end{tabular}


be higher than the groups that decided to stand aloof.

\section{Recommendation}

Violence is a very prominent issue in every human community. It has all ramification effects on all and sundry in the society. To this end, the following stake holders; the government and the general masses are expected to consider the recommendations in this work as a veritable tool which have the potential of mitigating all forms of violence in the community.

The government at all levels should ensure that adequate representation among the federating units in a country in terms of fiscal and power distribution. The monetary allocations to the federating units should be relative to their capability and in special cases, the contributory strength of the units to the federal purse. This implies that a general allocation will be made to all according to the federal arrangement but a special allocation will also be made to some quarters whose contributory effects on the federation has enormous effect.

The government should also look into the critical geographical differences in terms of land mass, natural resources and endowments. This will enables the government to be able to evenly utilise all the federating units' area of strength. By so doing, it will make them relevant to the other federating units and further increase their chance in the special allocations due to enormous contribution they will be making to the federation account.

The government should also consider the line of division in the ethnic groups and religious lines of separation within the community so as to balance up policies which may be ethnoreligious sensitive. By this, ethnic chauvinism and religious bigotry will be reduced to the best minimum. This will also ensure the greatest happiness of the greatest number of people in the polity. Eventually this will thereby cumulate into a reduction in political tension and a resultant violence will be delayed or prevented.

The government is also enjoined to keep sensitising the general populace on the need for a peaceful co- existence in the community amidst of religious and ethnic difference. This will make the community to exist in mutual benefits and continuous sustenance and tolerance. The religious body and the various heads of the ethnic groups among the general populace are enjoined to form alliance with the government to propagate tolerance sensitization to the whole populace

The general masses are also enjoined to channels their grievances to the right quarters of the government instead of self effected justice. This will reduce the resultant effect of retaliations and violence in the community. Ethnicity and extreme religious views should be reduced to the barest minimum by each individual by overlooking the difference in other ethnic or religious groups.

\section{Conclusion}

Urban violence emanating from geographical delimitations is very sensitive boiling points and pots of explosives in the polity inimical to the survival of the community or it ultimately pull down. This work had shown that the geographical delimitating issues such as state creation, boundary adjustment, federal character and affirmative action are sensitive to the survival of any democracy in the world. The democracies and polities of Nigeria, Ghana and South Africa are considered as a yardstick to other multi ethnic democracies all over the world.

The answers obtained from the analysis of findings to the research question however centres on the facts that violence ensuing from the geographical delimitations is easily escalating. The societies that place high premium on ethnic alignments have much violence in the issues that 
relates to geographical delimitations. However, when the geographical differences are streamlined peace will ensue to a large extent.

Finally, the fact that we have divergent views of the state and democracies due to the deep line of divisions in the ethnic wing and the religious wing in most polity is no longer a new phenomenon; the state survival of the polity should be the topmost priority of everyone in the federating unit of the state. Violence emanating from geographical delimitations can drastically be reduced if the state takes care of the natural dividing line by simply removing it from the federating units' psychoanalytical mindsets.

\section{Reference}

Esman, M. (1994); Ethnic Politics New York: Cornell University Press.

Gurr, R. (1971); Why Men Rebel, New Jersey: Princeton University Press.

Holzer H. and Neumark D.( 2005); Affirmative Action: What Do We Know? Journal of Policy Analysis and Management

Krause, K., Muggah, R. and Gilgen, E. (2011); Global Burden of Armed Violence 2011.Cambridge: Cambridge University Press.

Laurent Fourchard (2010); Lagos, Koolhaas and Partisan Politics in Nigeria International Journal of Urban and Regional Research DOI:10.1111/j.1468-2427.2010.00938.x

Mayer M. (2003); The Onward Sweep of Social Capital: Causes and Consequences for Understanding Cities, Communities and Urban Movements International Journal of Urban and Regional Research Volume 27.1

McCann E. (2007); Inequality and Politics in the Creative City-Region: Questions of Livability and State Strategy International Journal of Urban and Regional Research Volume 31.

Muggah R. (2012); Researching the Urban Dilemma: Urbanization, Poverty and Violence. IDRC Canada

Neha Sami (2013); From Farming to Development: Urban Coalitions in Pune, India

International Journal of Urban and Regional Research Volume 37.1

Nwozor A. (2014); Power Rotation, Ethnic Politics and the Challenges of Democratization in Contemporary Nigeria African Study Monographs, 35(1)

Parlette V. and Cowen D. (2010); Dead Malls: Suburban Activism, Local Spaces, Global Logistics International Journal of Urban and Regional Research Joint Editors and Blackwell Publishing Ltd

Simbane, A. (2002); Minority and Power Sharing in Nigeria, NISER Monograph Research Ibadan

Sisk, T. (1996); Power-Sharing and International Mediation in Ethnic Conflicts, Carnegie Corporation of New York, United States Institutes of Peace, Washington D.C

University of Oregon (2003); An Overview Of Services And Complaint And Grievance Procedures Office of Affirmative Action and Equal Opportunity, Eugene, Oregon. 


\title{
Насилие в городах и демографические разграничения в рамках демократического правления
}

\author{
Алуко Опейеми Идоуу \\ Университет Илорина \\ Штат Квара, Нигерия
}

\begin{abstract}
Насилие в городах достигло глобального хаотического этапа, который требует срочного решения проблемы. Приведен краткий обзор действий, рекомендуемых для решения этой глобальной угрозы. Демократические разграничения были определень в этой работе в качестве источника повторяющегося насилия в городах в большинстве государств. Они включают в себя создание государств и формуль зонирования, инициативы равноправия и принципь федерализации. Что касается этих усилий, в данной статье рассматривается вопрос, каковы последствия демографического разграничения для демократического мира, которые могут быть незаметными, но при этом значительными и изменчивыми в различных государствах. Для проверки фактов о том, что насилие в городах является результатом лишения группь людей их прав и преимуществ, используется теория относительной депривачии. Методология исследования включает в себя анализ данньх проекта «Афробарометр» по национальной и этнической идентичности, обеспечению безопасности и общему восприятию экономического уровня. В настоящем исследовании приведень данные по 2400 респондентам из Нигерии, Ганы и Южной Африки соответственно. Дань рекомендации по обеспечению адекватного представительства среди федеральньх единиц в стране с точки зрения фискальных и критических географических различий. Сделан вывод, что насилие, являющееся результатом географических разграничений, быстро растет, но если систематизировать географические различия, наступит мир.
\end{abstract}

Ключевые слова: формуль зонирования, инициативы равноправия, создание государства, федеральный, насилие в городах и относительная депривация.

Научная специильность: 23.00.00- политология. 